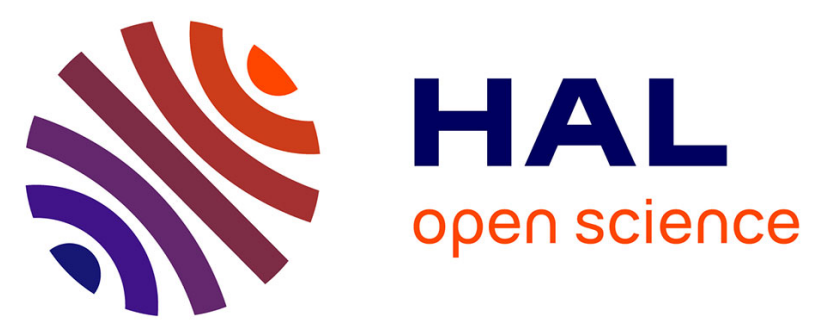

\title{
Mutants of the tumour suppressor p53 L1 loop as second-site suppressors for restoring DNA binding to oncogenic p53 mutations: Structural and biochemical insights
}

Assia Merabet, Hellen Houlleberghs, Kate Maclagan, Ester Akanho, Tam

T.T. Bui, Bruno Pagano, Alex F. Drake, Franca Fraternli, Penka V Nikolova

\section{To cite this version:}

Assia Merabet, Hellen Houlleberghs, Kate Maclagan, Ester Akanho, Tam T.T. Bui, et al.. Mutants of the tumour suppressor p53 L1 loop as second-site suppressors for restoring DNA binding to oncogenic p53 mutations: Structural and biochemical insights. Biochemical Journal, 2010, 427 (2), pp.225-236. 10.1042/BJ20091888 . hal-00479288

\section{HAL Id: hal-00479288 https://hal.science/hal-00479288}

Submitted on 30 Apr 2010

HAL is a multi-disciplinary open access archive for the deposit and dissemination of scientific research documents, whether they are published or not. The documents may come from teaching and research institutions in France or abroad, or from public or private research centers.
L'archive ouverte pluridisciplinaire HAL, est destinée au dépôt et à la diffusion de documents scientifiques de niveau recherche, publiés ou non, émanant des établissements d'enseignement et de recherche français ou étrangers, des laboratoires publics ou privés. 


\section{Running Title: Structural insights of p53 loop L1 mutants}

\section{Mutants of the tumour suppressor p53 L1 loop as second-site suppressors for restoring DNA binding to oncogenic p53 mutations: Structural and biochemical insights}

Assia Merabet ${ }^{1}$, Hellen Houlleberghs ${ }^{1}$, Kate Maclagan ${ }^{1}$, Ester Akanho ${ }^{1}$, Tam T. T. Bui ${ }^{1}$, Bruno Pagano $^{2,3}$, Alex F. Drake ${ }^{1}$, Franca Fraternali ${ }^{2}$ and Penka V. Nikolova ${ }^{1, *}$

King's College London, School of Biomedical \& Health Sciences, Dept. of Biochemistry \& ${ }^{1}$ Pharmaceutical Science Research Division, Franklin-Wilkins Building, 150 Stamford St., London, SE1 9NH; ${ }^{2}$ Randall Division of Cell and Molecular Biophysics, New Hunts House, London, SE1 1UL,United Kingdom; ${ }^{3}$ Dipartimento di Scienze Farmaceutiche, Universita di Salerno, via Ponte Don Melillo, Fisciano (SA), I84084, Italy

*To whom Correspondence should be addressed. Phone: +44(0) 207-848-4276; Fax: +44(0) 207-848-4500; E-mail: penka.nikolova@kci.ac.uk

To assess the potential of mutations from the L1 loop of the tumour suppressor p53 as second-site suppressors, the effect of H115N and S116M on the p53 "hot spot" mutations has been investigated using the double mutant approach. The effects of these two mutants on the p53 "hot spots" in terms of thermal stability and DNA binding were evaluated. The results show that: (1) mutants $\mathrm{H} 115 \mathrm{~N}$ and $\mathrm{S} 116 \mathrm{M}$ are thermally more stable than wild-type p53; (2) H115N but not S116M is capable of rescuing the DNA binding of one of the most frequent $\mathrm{p} 53$ mutants in cancer, R248Q, as shown by binding of $\mathrm{R} 248 \mathrm{Q} / \mathrm{H} 115 \mathrm{~N}$ to gadd45; (3) the double mutant R248Q/H115N is more stable than wild-type p53; (4) the effect of $\mathrm{H} 115 \mathrm{~N}$ as a second-site suppressor to restore DNAbinding activity is specific to R248Q but not to R248W; (5) molecular dynamics simulations indicate that $\mathrm{R} 248 \mathrm{Q} / \mathrm{H} 115 \mathrm{~N}$ has conformation similar to wild type-like $\mathrm{p} 53$, which is distinct from that of R248Q. These findings could be exploited in designing strategies for cancer therapy to identify molecules that could mimic the effect of $\mathrm{H} 115 \mathrm{~N}$ in restoring function to oncogenic p53 mutants.

Key words: p53 mutants, cancer, stability and folding, DNA-binding; molecular dynamics simulations 


\section{INTRODUCTION}

The p53 tumour suppressor protein is a key regulator of the signalling pathways implicated in tumorigenesis and presents a classic example of one of the most prevalently mutated proteins in human cancer. In response to various stress stimuli, p53 activates a network of genes involved in cell cycle arrest, apoptosis and other vital biological processes $[1,2]$. In the majority of human cancers, p53 function is abrogated either due to mutations in p53 or elsewhere in the p53 signalling pathway. The new release of the IARC TP53 mutational database contains 26,597 somatic mutations (R14, November, 2009). Importantly, the p53 mutational status has been associated with poor prognoses in a range of human cancers [3] and p53 is the most commonly mutated gene in breast and colon cancers [4]. Given that p53 is implicated in over $50 \%$ of all human cancers, it is not surprising that identifying strategies for restoring function to cancercausing p53 mutations has attracted great interest $[1,2,5-8]$. The inherent complexities of the p53 functions are reflected in the intrinsic structural organisation of the protein. The majority of mutations are found, is the p53 DNA-Binding Domain, DBD, the structure of which was first solved by Cho et al. in 1994 [9]. The 'hot spot' residues are the most frequently mutated amino acids in p53 protein and have been classified as 'contact' (R248 and R273) or 'structural' (R175, G245, R249, and R282) [9].

The structural consequences of the most frequent cancer-associated mutations on the function of p53 have been extensively reviewed $[5,6,10]$. Biophysical, biochemical and functional studies have highlighted the fact that there is no single bullet approach to restore the function to p53 cancer-associated mutants and that a tailor-made approach has to be applied depending on the intrinsic effect(s) of the individual amino acid substitution [5, 7, 11-17]. Mutations in p53 can affect the thermodynamic stability and hence the structural integrity of the p53DBD, the DNA-binding surface and the conformation for protein-DNA or protein-protein interactions $[6,10,13,16-20]$. The thermodynamic stability of p53 mutants itself can vary. Mutants such R248Q and $\mathrm{R} 273 \mathrm{H}$ for example, have marginal effect on the stability, while others (V143) are dramatically destabilized $[13,16,17]$.

The majority of the mutations are clustered at the protein-DNA binding interface and tumour-derived mutations in L1 loop (amino acid residues 112-124) are not frequently encountered in cancer. Hence the L1 loop has been termed a mutational "cold spot" [19, 21-23]. Structurally, L1 loop is part of the loop-sheet-helix (LSH) motif of the p53 DBD and contains the only three amino acid residues that directly contact DNA. The DNAcontact residue $\mathrm{K} 120$ as well as $\mathrm{S} 121$, are the main residue affected by the conformational change the loop undergoes upon binding to DNA [5, 24]. Structural studies have shown that $\mathrm{L} 1$ loop is one of the most mobile regions of the core domain and it packs loosely against the core frame mainly with side chain contacts. Crystal structures of core domain mutants [5, 25-28], and wild-type p53 [29, 30], indicate some disorder in parts of the L1 loop structure showing structural flexibility. According to molecular dynamics simulations, residues L114, H115, S116 and G117 make up the most flexible region of the loop [19]. Studies comparing human and worm forms of p53 concluded that loop L1 is one of the most promising regions for stabilization of p53 structure [31]. Substituting residue serine 116 with a methionine, without disturbing the wild-type conformation, stabilized L1 loop. In addition, several studies have reported that some mutations (such as H115N, S121F; T123P) in the L1 loop possess superior binding properties relative to wild type p53 or altered binding sequence specificity [21, $23,32,33]$. A recent report showed that $\mathrm{H} 115 \mathrm{~N}$ has an enhanced DNA binding, was more effective in inducing p53 target genes (such as p21 and PIG3) as well as arresting cells in G1, but was apoptotically impaired when compared with wild type p53 [21]. 
Another study, employed the use of in vitro compartmentalization (IVC) to select for p53 mutants with altered affinities for p53 response elements associated with the growth arrest regulator p21 and the pro-apoptotic PUMA gene [34]. Both studies have shown that $\mathrm{T} 123 \mathrm{~A}$ mutant increases transactivation in vitro and in vivo, particularly for proapoptotic response elements [23, 34]. Joerger et al. reported that the T123A mutation does not confer any structural changes in the loop L1 region [27]. However, structural studies suggested that residues in loop L1 form part of the p53 dimer-dimer interface [5]. Hence, the T123A mutation might contribute to stronger inter-domain interactions that stabilize tetramer binding to pro-apoptotic DNA. In addition to the several mutations in L1 loop that have previously been reported to enhance the affinity of p53 for specific DNA sequences [21, 32, 33], others have been identified as second-site suppressors, including the T123A mutation [12]. Yet the molecular mechanisms of the latter remain to be elucidated. Different approaches have been exploited to rescue the function of cancer-associated mutants with varied success. The "second-site suppressor mutations" can rescue the function of some p53 cancer-related mutants $[12,17,35,36]$. Recently, targeted rescue of a destabilized p53 mutant, Y220C, has been investigated by an in- silico screening approach [11]. Peptides targeting mutant p53 to induce apoptosis have been employed to inhibit the oncogenic function of mutant p53 [8, 14, 15, 37].

In this paper the role of two p53 mutations (H115N and S116M) located in L1 loop as "second-site suppressors" has been probed. Key p53 cancer-related mutations alone and as double mutants in combination with one of the two selected L1 loop mutations were used as a model system. The ability of the DNA contact mutant R248Q, the second most frequent mutation in cancer, which accounts for 855 out of 26597 of all single base substitutions (IARC TP53 mutation database, R14 release, Nov. 2009) to bind DNA was restored by introducing H115N. Molecular dynamics simulations complemented the experimental data and provided further insights into the mechanism of rescue of DNA binding by second-site suppressors from L1 loop.

\section{MATERIALS AND METHODS \\ Site-directed mutagenesis. Protein expression and purification}

Cloning of the sequence coding for wild-type human p53DBD (a.a. 94-312) was achieved using $2.9 \mathrm{~kb}$ pRSET(A) expression vector (Invitrogen), which was modified so that it did not have the 6xHis tags $[16,17,38,39]$. The p53 mutants were generated using the Quick-Change site-directed mutagenesis kit (Stratagene). Proteins were expressed into E. coli C41(DE3) cells. Single colonies were selected and added to $5 \mathrm{ml}$ of sterile 2xTY media supplemented with Ampicillin $(100 \mu \mathrm{g} / \mathrm{ml})$. The cultures were incubated at $37^{\circ} \mathrm{C}$ with shaking at $250 \mathrm{rpm}$. $5 \mathrm{ml}$ culture was added to $500 \mathrm{ml}$ sterile $2 \mathrm{xTY}$ media containing Ampicillin $(100 \mu \mathrm{g} / \mathrm{ml})$ and incubated at $37^{\circ} \mathrm{C}$ with shaking at $250 \mathrm{rpm}$. Once an absorbance of 0.6-0.8 was reached, the temperature was reduced to $20-22^{\circ} \mathrm{C}$ and cultures were induced with $1 \mathrm{mM}$ IPTG overnight. The cultures were than centrifuged at $8500 \mathrm{rpm}$ for 25 minutes at $4^{\circ} \mathrm{C}$. The supernatant was discarded and the cells harvested, frozen in liquid nitrogen and stored at $-80^{\circ} \mathrm{C}$ for later use or used for protein purification directly $[38,39]$. The protein was released by re-suspending and incubating the cell pellets in a mixture of $50 \mathrm{ml}$ Bug buster protein extraction reagent (Merck), 1 tablet (Roche) EDTA-free protease inhibitor and $5 \mu 1$ benzonase nuclease (Merck) per $10 \mathrm{~g}$ of cells. The resulting suspension was centrifuged at $13000 \mathrm{rpm}$ for 25 minutes at $4^{\circ} \mathrm{C}$. The soluble fraction was collected from which the protein was purified using an ion exchange-, heparin affinity- and a gel filtration columns connected to an AKTA prime system equipped with the Prime view software. 


\section{Circular Dichroism (CD)}

Protein samples were concentrated to $\sim 0.2 \mathrm{mg} / \mathrm{ml}$ using Amicon Ultra-15 centrifugal units, 10,000 NMWL (Millipore). Buffer was exchanged to $10 \mathrm{mM} \mathrm{Na}$ phosphate, $100 \mathrm{mM} \mathrm{NaCl}$ and 4mM DTE, pH 7.2, using Nap-10 Sephadex G25 columns (GE Healthcare). The samples were filtered using $0.2 \mu \mathrm{m}$ Anatop filters (Whatman). All Circular Dichroism spectra were acquired using an Applied Photophysics Chirascan. $0.5 \mathrm{~mm}$ suprasil rectangular cells (Hellma) were used in the Far-UV region 260-195nm. Temperature was controlled using a Melcor thermoelectric Peltier unit. Far-UV CD spectra of the proteins were recorded with a $1 \mathrm{~nm}$ spectral bandwidth, a $0.5 \mathrm{~nm}$ step size and a 3.0 second time-per-point at $20^{\circ} \mathrm{C}, 4^{\circ} \mathrm{C}$ and $37^{\circ} \mathrm{C}$. Protein apparent melting temperatures $(\mathrm{Tm})$ were monitored at a $222 \mathrm{~nm}$ wavelength between $20^{\circ} \mathrm{C}$ and $60-90^{\circ} \mathrm{C}$. The temperature was increased at a rate of $1^{\circ} \mathrm{C} / \mathrm{min}$ with a $1^{\circ} \mathrm{C}$ step size and a $2^{\circ} \mathrm{C}$ tolerance. Measurements were made with a $10 \mathrm{~s}$ time-per-point and temperatures measured with a thermocouple probe directly in the protein solution. Far-UV spectra were recorded again after cooling to $20^{\circ} \mathrm{C}$. Spectral data are reported as the difference in the absorbance of right- and left-handed circularly polarized light, $\Delta \mathrm{A}=\left(\mathrm{A}_{\mathrm{L}}-\mathrm{A}_{\mathrm{R}}\right)$ and converted to the differential molar circular dichroic extinction coefficient, $\Delta \varepsilon=\left(\varepsilon_{\mathrm{L}}-\varepsilon_{\mathrm{R}}\right)$, where $\Delta \varepsilon$ has the unit of litre $\mathrm{mol}^{-1} \mathrm{~cm}^{-1}$.

\section{Electro Mobility Shift Assay (EMSA)}

DNA-binding properties of wild type and p53 mutants were tested using EMSA and gadd45 30mer (forward: 5'-GTACAGAACATGTCTAAGCATGCTGGGGAC-3'; reverse: 5'- GTCCCCAGCATGCTTAGACATGTTCTGTAC-3'). Lyophilized ss DNA oligos were purchased from Sigma Genosys and re-suspended in $10 \mathrm{mM}$ Tris- $\mathrm{HCl}, \mathrm{pH}$ 8.0 and $100 \mathrm{mM} \mathrm{NaCl}$ to give a final concentration of $100 \mu \mathrm{M}$. To anneal the oligos, an identical amount of each oligo was mixed in an eppendorf tube then heated at $99^{\circ} \mathrm{C}$ for 5 minutes and slowly cooled down to room temperature. For the EMSA studies, $10 \mu 1$ of protein solution with increasing amounts of protein $\left(1 \mathrm{x}, 2 \mathrm{x}, 4 \mathrm{x}\right.$ and $\left.8 \times 10^{-5} \mathrm{M}\right)$ were titrated into a fixed amount of DNA $\left(5 \times 10^{-6} \mathrm{M}\right)$. Each lane in the gel contained $10 \mu \mathrm{l}$ of $10^{-5} \mathrm{M}$ DNA mixed with $10 \mu \mathrm{l}$ of the protein sample at the concentrations listed above. Proteins were first concentrated using Amicon Ultra-15 centrifugal units, 10,000 NMWL (Millipore). Buffer was exchanged to $50 \mathrm{mM}$ Tris $\mathrm{HCl}, \mathrm{pH} 7.2,150 \mathrm{mM} \mathrm{NaCl}$, $4 \mathrm{mM}$ DTT, pH 7.2, using Nap-10 Sephadex G25 columns (GE Healthcare). The protein solutions were filtered using $0.2 \mu \mathrm{m}$ Anatop filters (Whatman) and used to prepare $10 \mu 1$ samples at the required concentrations. After incubation at room temperature for 20-30 min, the mixtures (20 $\mathrm{ll}$ each) were run on a $0.7 \%$ agarose gel, in TB running buffer, at 60-90 V for 45-50 min at room temperature to analyze for complex formation. Gels were soaked in $200 \mathrm{ml}$ water supplemented with $100 \mu 1$ of $1 \mathrm{mg} / \mathrm{ml}$ ethidium bromide and incubated, for 20-30 min prior to visualisation.

\section{Molecular Modeling and Molecular Dynamics Simulations (MD)}

The in silico mutants were generated using Pymol [40]. As starting structure we chose the crystal structure of the human p53 core domain determined in the absence of DNA with the highest resolution available (2.05 $\AA$; pdb code: 2 ocj) [41]. The initial structures of the mutants were energy minimized in vacuo by 1000 steps of the steepest descent method. Molecular dynamics simulations on the wild-type p53 core domain and on the in silico generated mutants H115N, S116M, R248Q, R248Q/H115N and R248Q/S116M were performed with the GROMACS package [42] using the 53A6 parameter set of GROMOS96 force field [43]. The molecules were neutralized with $\mathrm{Na}^{+}$ions (placed following electrostatic potential values) and solvated in boxes containing about 13300 
SPC water molecules [44]. Initially, water molecules and ions were relaxed by energy minimization and allowed to equilibrate for $200 \mathrm{ps}$ of $\mathrm{MD}$ at $300 \mathrm{~K}$ with the solute molecules restrained at their initial geometry. The bonds were constrained by the LINCS algorithm [45] with a force constant of $3000 \mathrm{~kJ} \mathrm{~mol}^{-1} \mathrm{~nm}^{-2}$. Finally, the equilibrated systems were subjected to unrestrained MD simulations for $10 \mathrm{~ns}$. Simulations were carried out with periodic boundary conditions at a constant temperature of $300 \mathrm{~K}$. The Berendsen and v-rescale algorithms were applied for pressure and temperature coupling, respectively. The particle mesh Ewald method (PME) was used for the calculation of electrostatic contribution to non-bonded interactions (grid spacing of $0.12 \mathrm{~nm}$ ) [46-48]. MD trajectories were analyzed using GROMACS analysis tools. The Dynamite server (www.biop.ox.ac.uk/dynamite) [49] was used to carry out principal component analysis (PCA) of the MD trajectories. Images were produced with Visual Molecular Dynamics (VMD 1.8.6) [50].

\section{RESULTS}

Since the majority of the p53 cancer-associated mutants are located in the p53 DBD, a construct containing residues 94-312 was used. The locations of the mutants subjected to the above studies onto the 3D structure of the p53 are depicted schematically in Figure 1. We aimed to characterize the folding, stability and DNA-binding properties of $\mathrm{H} 115 \mathrm{~N}$ and S116M as well as a select set of double mutants generated using key p53 "hot spot" mutants plus either H115N or S116M and compare them to wild-type p53.

\section{Accessing the folding of the proteins using Far-UV CD at different temperature}

In order to access the impact of p53 L1 loop mutants onto the oncogenic mutations as well as the folding state of the proteins, both single and double mutants were subjected to detailed Far-UV CD scans at various temperatures, namely 4, 20, 37 and cooling to $20^{\circ} \mathrm{C}$ after heating to $37^{\circ} \mathrm{C}$. The results for the wild-type p53 and the single mutants are presented in Figure 2 (A-I) and that for the double mutants - in Figure 3 (A-J), respectively. The Far-UV CD spectrum of wild-type p53 DBD domain has been recorded previously [38] and used here as control in order to compare it with the mutants of interests (Figure $2 \mathrm{~A}$ ). The spectra of wild-type p53 DBD at $20^{\circ} \mathrm{C}$ and $4^{\circ} \mathrm{C}$ are essentially identical but different from the spectra recorded at $37^{\circ} \mathrm{C}$. This implies that at $37^{\circ} \mathrm{C}$, wild-type p53 DBD has undergone partial unfolding, which is irreversible upon cooling back to $20^{\circ} \mathrm{C}$ (data not shown). The spectra of $\mathrm{H} 115 \mathrm{~N}$ and $\mathrm{S} 116 \mathrm{M}$ are shown on Figure $2 \mathrm{~B}$ and $\mathrm{C}$. The $\mathrm{H} 115 \mathrm{~N}$ mutant is similar to the wild-type p53 since the scans at $20^{\circ} \mathrm{C}$ and cooling back to $4^{\circ} \mathrm{C}$ are virtually identical, but they differ from the spectra recorded at $37^{\circ} \mathrm{C}$. However, $\mathrm{S} 116 \mathrm{M}$ shows almost identical scans at all the temperatures tested (Fig. 2C). The scans indicate that the conformations for $\mathrm{H} 115 \mathrm{~N}$ and S116M are different from that of the wild-type $\mathrm{p} 53$ protein at $20^{\circ} \mathrm{C}$ (Figure $2 \mathrm{~A}, \mathrm{~B}$ and $\mathrm{C}$ ). The data for the cancer associated mutations, namely, R248Q, R248W, R249S, R273H, V143A and G245S, are shown in Figure 2 D-I, respectively.

The variable temperature Far-UV CD spectra for the corresponding double mutants recorded under the same conditions are displayed in Figure 3 (A-J). As shown in Figure $3 \mathrm{~A}$ and $\mathrm{B}$, the spectra of $\mathrm{R} 248 \mathrm{Q} / \mathrm{H} 115 \mathrm{~N}$ and that of $\mathrm{R} 248 \mathrm{Q} / \mathrm{S} 116 \mathrm{M}$ at $20^{\circ} \mathrm{C}$, then at $4^{\circ} \mathrm{C}$ and $37^{\circ} \mathrm{C}$ basically overlapped. Interestingly, the spectra of the oncogenic mutant R248Q (Figure 2D) differ from that of the double mutant R248Q/H115N (Figure 3A). Specifically, the scans at $37^{\circ} \mathrm{C}$ are near identical with those recorded at $20^{\circ}$ and at $4^{\circ} \mathrm{C}$ for the double mutant vs. the R248Q alone. Similar observations were seen for R273H (Figure $2 \mathrm{G}$ ) vs. the double mutant R273H/H115N (Figure 3E). The spectra for R249S 
(Figure $2 \mathrm{~F}$ ) on the other hand when compared with those of the double mutants R249S/H115N (Figure 3G) and R249S/S116M (Figure 3H) seemed to suggest that at $37^{\circ} \mathrm{C}$ both the single and double mutants undergo unfolding. The scans for R248W (Figure $2 \mathrm{E}$ ) and that of R248W/H115N (Figure 3C) are almost identical but different than R248W/S116M (Figures $3 \mathrm{D}$ ) where all scans overlapped, suggesting that the latter double mutant seems to be folded at physiological temperature, consistent with the observation for the double mutant R248Q/S116M (Figure 3B). The spectra for G245S and the G245S/H115N are only slightly different at all temperatures tested (Figure 2I and Figure 3J). Reviewing the CD data allows the classification of the p53 proteins studied here in two groups: those with conformation similar to wild-type p53, R248Q, R248W, R249S, R273H, R248W/H115N, R273H/H115N, R273H/S116M, R249S/S116N, R248Q/H115N, V143A/H115N and those that differ from wild-type p53 conformation, namely H115N, S116M, V143A, G245S, R248W/S116M, R248Q/S116M, G245S/H115N, R249S/H115N.

\section{Thermal stability of the p53 cancer-associated mutants and the "second-site" suppressors relative to the corresponding double mutants}

The selection of mutant proteins studied here is an illustrative example of the intrinsic complexities of p53 protein. The thermal melting curves of p53 showed broadly two different phenomena: unfolding and aggregation. The thermal stability of wild-type p53 is around $42^{\circ} \mathrm{C}$ (Figure 4), which is in good agreement with previously published data for the same construct $[13,16,38]$. Wild-type p53 is relatively conformationally stable between $4^{\circ} \mathrm{C}$ and $32^{\circ} \mathrm{C}$. Between $32^{\circ} \mathrm{C}$ and $38^{\circ} \mathrm{C}$ there is evidence of unfolding; above $38^{\circ} \mathrm{C}$ p53 forms irreversible aggregates with an apparent $\mathrm{T}_{\mathrm{m}} \sim 42^{\circ} \mathrm{C}$. The $\mathrm{H} 115 \mathrm{~N}$ single mutant shows changes only above $32^{\circ} \mathrm{C}$ which cannot be readily distinguished from the aggregation stage that gives $\mathrm{T}_{\mathrm{m}} \sim 42.4^{\circ} \mathrm{C}$ (Figure 4). The $\mathrm{S} 116 \mathrm{M}$ single mutant shows no evidence of change until $40^{\circ} \mathrm{C}$. Above $40^{\circ} \mathrm{C}$ only the aggregation step is observed with $\mathrm{Tm} \sim 43.3^{\circ} \mathrm{C}$ (Figure 4 ). The $\mathrm{R} 248 \mathrm{Q}$ single mutant is relatively unchanged until $34^{\circ} \mathrm{C}$; the ensuing dominant aggregation has $\mathrm{T}_{\mathrm{m}} \sim 43.4^{\circ} \mathrm{C}$. The $\mathrm{R} 273 \mathrm{H}$ mutant (Figure 4) is stable up to $38^{\circ} \mathrm{C}$; higher temperature showed only the aggregation step with $\mathrm{T}_{\mathrm{m}} \sim 41.3^{\circ} \mathrm{C}$. The V143A single mutant (Figure 4) is stable up to $25^{\circ} \mathrm{C}$ when a pronounced unfolding stage is observed with the onset of aggregation at $33^{\circ} \mathrm{C}$ giving a $\mathrm{T}_{\mathrm{m}} \sim 37^{\circ} \mathrm{C}$.

The $\mathrm{R} 248 \mathrm{Q} / \mathrm{H} 115 \mathrm{~N}$ double mutant is stable (Figure 4) until $33^{\circ} \mathrm{C}$ at which point unfolding occurs; aggregation sets in at $42^{\circ} \mathrm{C}$ giving a $\mathrm{T}_{\mathrm{m}} \sim 44.4^{\circ} \mathrm{C}$. The $\mathrm{R} 248 \mathrm{Q} / \mathrm{S} 116 \mathrm{M}$ double mutant is markedly stable up to $38^{\circ} \mathrm{C}$, at which point a pronounced unfolding stage occurs followed by the aggregation onset at $44^{\circ} \mathrm{C}$ giving a $\mathrm{T}_{\mathrm{m}} \sim 46.1^{\circ} \mathrm{C}$ (Figure 4). The R273H/S116M double mutant (Figure 4) appears to be the least flexible mutant in this set and the most resistant to aggregation. Unfolding commences at $36^{\circ} \mathrm{C}$ with evidence of aggregation beginning at $43^{\circ} \mathrm{C}$. The $\mathrm{R} 273 \mathrm{H} / \mathrm{H} 115 \mathrm{~N}$ double mutant (Figure 4) is also very stable up to $40^{\circ} \mathrm{C}$. There is no evidence of unfolding before the aggregation step which commences at $40^{\circ} \mathrm{C}$ giving a $\mathrm{T}_{\mathrm{m}} \sim 42.7^{\circ} \mathrm{C}$. The $\mathrm{V} 143 \mathrm{~A} / \mathrm{H} 115 \mathrm{~N}$ double mutant (Figure 4) shows a minor hint of unfolding starting at $27^{\circ} \mathrm{C}$ with the aggregation process commencing at $33^{\circ} \mathrm{C}$ with a $\mathrm{T}_{\mathrm{m}} \sim 38^{\circ} \mathrm{C}$. Interestingly the two mutants from loop L1 H115N and S116M displayed higher thermal stability than wild type p53 DBD (Figure 4), as obvious from the melting curves. Most notably, the double mutant $\mathrm{R} 248 \mathrm{Q} / \mathrm{H} 115 \mathrm{~N}$ exhibited higher stability relative to the cancer-associated mutant R248Q as well as wild-type p53. Some cancer-associated mutants such as V143A (Figure 4) and R249S (data not shown) for example, exhibit lower apparent 
melting temperature, while others such as R273H (Figure 4) or G245S (data not shown) are only marginally less stable than the wild-type p53 DBD. The double mutants $\mathrm{R} 273 \mathrm{H} / \mathrm{H} 115 \mathrm{~N}$ and R273H/S116M (Figure 4) appear to be more stable that the cancer associated mutant R273H. Similar results were observed for V143A/H115N (Figure 4) and $\mathrm{R} 249 \mathrm{~S} / \mathrm{H} 115 \mathrm{~N}$ (data not shown). The $\mathrm{H} 115 \mathrm{~N}$ has raised the thermal stability of R249S with about $1.5-2^{\circ} \mathrm{C}$ from about 36.5 to $38.5^{\circ} \mathrm{C}$, that of $\mathrm{R} 273 \mathrm{H}$ from about 41.3 to $42.7^{\circ} \mathrm{C}$, and that of R248Q by about $1{ }^{\circ} \mathrm{C}$. Furthermore thermal destabilization was reported to correlate well with enhanced kinetics of unfolding at $37^{\circ} \mathrm{C}[51]$, namely mutants such as V143A and R249S unfolding an order of magnitude faster than wildtype $\mathrm{p} 53$, while $\mathrm{R} 273 \mathrm{H}$ and $\mathrm{G} 245 \mathrm{~S}$ unfold only slightly faster. Importantly, unfolding is associated with aggregation of mutants at $37^{\circ} \mathrm{C}$ i.e. the higher the unfolding the faster the aggregation.

\section{Investigating the DNA-binding of the p53 mutants by EMSA}

Having accessed the folding state and the thermal stabilities of the proteins we employed EMSA assays as a simple and effective way to screen for DNA binding activities. We selected the 30-mer ds gadd45 DNA as a model system since it is known that it binds to wild-type p53 core domain protein. The results of these tests are shown in Figures 5 and Supplementary Figure 1. The binding of wild-type p53 DBD (Figure 5A, lanes 2-5) and the two single mutants from L1 loop, H115N (Figure 5A, lanes 7-10) and S116M (Figure 5A, lanes 12-15) showed essentially similar binding properties to gadd45 ds DNA. Lanes 1, 6 and 11 showed free DNA as a control. The cancer-associated hot spot mutants, the double mutants containing the cancer hot spots plus either the $\mathrm{H} 115 \mathrm{~N}$ or the S116M were tested by the same method (Figure 5B-F). Remarkably, the double mutant $\mathrm{R} 248 \mathrm{Q} / \mathrm{H} 115 \mathrm{~N}$ (Figure 5B, lanes 12-15) exhibited a recovery for DNA binding to gadd45, which was almost similar to that of wild-type p53 DBD (Figure 5B, lanes 2-5). The addition of the second-site mutation $\mathrm{H} 115 \mathrm{~N}$ has "rescued" the DNA binding of the $\mathrm{R} 248 \mathrm{Q}$, one of the most mutated residues in cancer, which as shown on Figure 5B, lanes 7-10, does not bind to DNA on its own. The "rescue" effect is specific since the addition of S116M to R248Q or R248W did not rescue the DNA binding of the cancer hot spots as obvious from Figures $5 \mathrm{C}$ and D. We tested also the structural mutant R249S, which does not bind DNA on its own (Figure 5E and F, lanes 7-10, respectively). However, the addition of the $\mathrm{H} 115 \mathrm{~N}$ and or $\mathrm{S} 116 \mathrm{M}$ did not have any apparent effect on the DNA binding of the corresponding double mutants R249S/H115N (Figure 5E, lanes 12-15) and R249S/S116M (Figure 5F, lanes 12-15). Similarly, the effect of H115N on V143A, G245S and R273H was also tested (data not shown). While H115N enhanced the DNAbinding of V143A and G245S, which had already some partial DNA binding, the effect was not as dramatic as that of the R248Q. However, H115N did not result in enhanced DNA binding when included as part of the double mutant R273H/H115N. Similarly the addition of $\mathrm{H} 115 \mathrm{~N}$ to $\mathrm{R} 248 \mathrm{~W}$ (Figure S1, lanes 7-10) does not have any apparent effect on the DNA binding as obvious from the EMSA gel, which shows some marginal partial binding for R248W, similar to that of the double mutant R248W/H115N (Figure S1, lanes 12-15 of Supplementary Materials).

\section{Modelling the structures of H115N, S116M, R248Q, R248Q/H115N and $\mathrm{R} 248 \mathrm{Q} / \mathrm{S116}$ and analysis of their conformational behaviour}

To gain structural insights of the p53 L1 loop mutants, H115N and S116M, and their effect as potential "second-site" suppressors we performed Molecular Dynamics simulations. These produced stable trajectories as shown by macroscopic properties of the systems, such as potential and total energies (data not shown). The time evolution of 
the root mean square deviation (RMSD) values with respect to starting structures indicates that the proteins have reached stable structures (within 3.0 from the initial state) during the $10 \mathrm{~ns}$ long MD simulations (see Figure S2 of Supporting Materials). We first focus on $\mathrm{H} 115 \mathrm{~N}$ and S116M, to evaluate their effect on the region critical to DNA binding and their overall effect on the stability of the p53 DBD. The trajectories of the wild type and the two single L1 loop mutants were compared based on the residue root mean square fluctuations (RMSF) calculated over the last 4 ns of each simulations (Fig. 6). The RMSFs plots show a similar pattern but the mutants are generally fluctuating less than the wild type. In particular, differences were observed in the fluctuations of L1 and L2 loops and in the region connecting $\mathrm{H} 1$ and $\mathrm{S} 5$.

To analyze in more detail the stability of the L1 loop and its conformational changes during the trajectories, we calculated for the last $4 \mathrm{~ns}$ of each trajectory the number of hydrogen bonds (h-bonds) formed by residues of the L1 loop and S2 structural elements (stretch of residues 113-126) as well as the number of h-bonds formed between this stretch and the H2 helix residues (residues 277-289) (Table 1). In the wild-type simulation we observe that the h-bond between G117 and T125, initially present in the crystal structure, is lost after 2 ns of simulation, while the h-bond between S116 and C124 remains stable during the whole simulated time. Moreover, we observe that S116 gains two extra h-bonds during the trajectory, one more with C124 and one with T123, reaching an average of $3 \mathrm{~h}$-bonds in the L1 loop. By analyzing the h-bonds between the loop region and the $\mathrm{H} 2$ residues we observe that the interaction between $\mathrm{T} 118$ and R283, present in the crystal structure, is lost after 7 ns of simulation, while the h-bond between $\mathrm{T} 125$ and $\mathrm{R} 282$ remains stable. As a result the average $\mathrm{L} 1-\mathrm{H} 2 \mathrm{~h}$-bonds number over the last 4 ns of simulation is reduced to 1. As shown in Table 1, when the histidine 115 is changed to an asparagine the number of h-bonds between the loop region and the $\mathrm{H} 2$ helix remains unaltered while resulting in an increase of a total of 5 in the loop region. H115 is oriented toward the solvent in the wild-type crystal structure and in the MD simulation not forming any intra-molecular interaction. In the H115N mutant the asparagine forms two intra-molecular h-bonds, one with G117 and one with Y126. The h-bonds are formed by S116 and C124 (as found in the wild-type simulation) and between G117 and T125 (like in the crystal structure). The analysis of the Table 1 also reveals that S116M forms on average only one h-bond within the L1 loop, between the backbone of methionine 116 and the side-chain of T125. Comparison of the final structure of S116M with the wild-type (Fig. 6) shows that, despite there being fewer hbonds within the loop, the mutation seems not to disrupt the L1 conformation (in agreement with Nussinov and co-workers results) [19]. On the contrary, the mutation seems to diminish its conformational flexibility, reducing the fluctuations and increasing the interactions of the loop with the neighbouring H2 helix. The overall result from the analysis of the point mutants, H115N and S116M, is that they substantially preserve the native conformation of the L1 loop and decrease its fluctuation. H115N increases the number of "intra-loop" h-bonds, while S116M increases the number of loop-helix h-bonds. These results show that mutant $\mathrm{H} 115 \mathrm{~N}$ is stabilised intramoleculary and kept more rigid in a conformation that is more suitable for DNA binding, as hypothesised in the literature [21]. We examined R248Q to assess the effect of this mutation on the p53 core domain. Visual inspection of the trajectory and the principal component analyses (PCA) (see the movie in the Supporting Material) revealed that the mutation of residue $\mathrm{R} 248$ causes not only a rearrangement of the L3 loop but a consequent rearrangement of the whole region of the protein involved in binding to DNA. Indeed, once mutated, the L3 loop is freer to move because the 
repulsion previously present between R248 and R273 is eliminated. In addition, the $\mathrm{R} 273$, linked to the H2 helix by means of a salt bridge with D281, gains interactions with serine residues of L3 loop (S240 and S241) inducing a displacement of the H2 helix from its original positioning. The movement of the L3 loop also generates a rearrangement of the nearby loop connecting S7 and S8. The net effect of these rearrangements is that L1 loop moves away from the $\mathrm{H} 2$ helix as shown in Figure 7A-B. The distance between $\mathrm{C} \alpha$ atom of residue 248 and $\mathrm{C} \alpha$ atom of the closest residue of $\mathrm{H} 2$ (residue 285) was calculated to decrease from $15 \AA$ to $12.5 \AA$. The distance between the $\mathrm{C} \alpha$ atoms of residues 279 and 118 (two closest residues in the starting structure belonging to $\mathrm{H} 2$ helix and L1 loop, respectively) increased from $3.8 \AA$ to $14.4 \AA$. This concerted movement results also in the loss of h-bonds formed between the loop region and the helix (Table 1). The complex structural rearrangement caused by a single change in the amino acid sequence complement previous observations that R24Q behaves as both a contact and structural mutant [52]. Finally, we examined the two double mutants $\mathrm{R} 248 \mathrm{Q} / \mathrm{H} 115 \mathrm{~N}$ and $\mathrm{R} 248 \mathrm{Q} / \mathrm{S} 116 \mathrm{M}$ to evaluate the effect of concerted mutations on the L1 loop positioning. Figure 7C shows the final structures of $\mathrm{R} 248 \mathrm{Q} / \mathrm{H} 115 \mathrm{~N}$ and R248Q/S116M superimposed onto the structure of wild-type p53 core domain. The direct comparison of the structures shows clearly that the final structure of $\mathrm{R} 248 \mathrm{Q} / \mathrm{H} 115 \mathrm{~N}$ mutant remains close to the wild-type structure. On the other hand, the final structure of $\mathrm{R} 248 \mathrm{Q} / \mathrm{S} 116 \mathrm{M}$ resembles better the one obtained for the R248Q simulation. To analyse in detail the behaviour of the L1 loop, we computed the RMSD of $\mathrm{C} \alpha$ atoms of the loop (residues 113-123) for the native structure and the mutants $\mathrm{R} 248 \mathrm{Q} / \mathrm{H} 115 \mathrm{~N}$ and $\mathrm{R} 248 \mathrm{Q} / \mathrm{S} 116 \mathrm{M}$ (Fig. 7D). The plot shows that the structural positioning observed for the L1 loop of R248Q/H115N is comparable to the wild type, while the R248Q/S116M mutant shows a remarkable structural deviation in the $\mathrm{L} 1$ region. The calculation of the number of h-bonds reveals that there are 5 "intraloop" h-bonds in the L1 loop of R248Q/H115N, as observed for the single mutant H115N. In particular, three out of these five h-bonds are the same as those formed in the wild-type structure, and the other two are the same as those formed by N115 in the H115N mutant. For R248Q/S116M, we observe a large conformational change in the L1 region that allows $\mathrm{H} 115$ (orientated towards the solvent in the crystal structure and in all the other simulated structures) to form two h-bonds, one with G117 and one with A119. As for the R248Q mutant, no interactions are found between the L1 loop and the H2 helix, confirming similar conformational behavior for these two mutants. Overall, the R248Q mutation causes a large rearrangement of the protein in the region of the protein involved in the binding of the DNA and especially in the L1 loop. The original position of the $\mathrm{L} 1$ loop is not restored in the $\mathrm{R} 248 \mathrm{Q} / \mathrm{S} 116 \mathrm{M}$, but is restored in $\mathrm{R} 248 \mathrm{Q} / \mathrm{H} 115 \mathrm{~N}$ owning to the presence of the asparagine residue that stabilize intramolecularly the loop by forming two extra "intra-loop" h-bonds.

\section{DISCUSSION}

Several studies have highlighted the importance of L1 loop as highly modular region in the p53 structure, which is rarely mutated in cancer. Data from yeast-based, cell-free or cell-based assays in addition to molecular dynamics simulations have suggested a role for L1 loop in recognition of specific DNA sequences, transactivation and apoptosis by p53 $[19,22,23,33,34]$. To clarify further the intrinsic role of the mutations located in the L1 loop on the conformation, thermal stability and DNA binding of the protein, we performed detailed biophysical, biochemical and structural studies complemented with molecular dynamics simulations using mutations $\mathrm{H} 115 \mathrm{~N}$ and $\mathrm{S} 116 \mathrm{M}$ as a model. The experimental $C D$ data showed that the two mutants are more thermally stable than the 
wild-type p53. This observation was based on the apparent melting temperatures of the mutant proteins and was in good agreement with our molecular dynamics simulations data. Pan et al. have reported similar observations for S116M during systematic computational mutagenesis of L1 loop [19]. Ser 116 was selected as a representative of L1 loop and mutated to 14 other amino acid residues. All mutants were subjected to molecular dynamics simulations, with S116M exhibiting the highest stability largely due to the reduced conformational flexibility of L1 loop. These computational studies complement our previous experimental finding that the "super-stable" p53 mutant M133L/V203A/N239Y/N268D exhibited $2.6 \mathrm{kcal} / \mathrm{mol}$ higher thermodynamic stability than the wild-type p53 DBD [16]. The crystal structure of the super stable mutant revealed that the enhanced thermodynamic stability is due to the more rigid structure (reduced plasticity) and provided insights into the mechanism of rescuing p53 oncogenic mutations [25]. It was reported that changes in the thermodynamic stability of p53 were associated with reduced level of folded and hence functional p53 [53]. The thermal behaviour of p53 and some of its mutants has been previously monitored by Differential Scanning Calorimetry (DSC) and fluorescence [13, 16-18]. The study reported here employs CD. The apparent melting temperatures, Tm, for all proteins of interest were measured by $C D$ at $222 \mathrm{~nm}$ in order to obtain semi-quantitative measures about their thermal stabilities and flexibilities. Since all the proteins unfold irreversibly, the thermal melting curves are still a useful way to provide an assessment of the thermal stability of the mutants. The first thermal step involves a secondary structure change, which relates to the flexibility of the proteins. The second step at higher temperatures involves irreversible aggregation. Which of the two processes need to be addressed to reverse mutant-induced loss of DNA binding is open to question. Characterising the first unfolding stage is difficult as it is immediately followed by irreversible aggregation stage that dominates the thermal studies and is largely responsible for the apparent Tm. Pan et al., showed that the 14 designed mutants displayed a wide range of stabilities, ranging from completely destabilised, such as S116P and S116C, to highly stabilised, such as S116M, S116L and S116N [19]. Only S116M was predicted to be capable of substantially preserving the native conformation of the mobile L1 loop of p53 DBD. Given that wild-type p53 is only moderately stable $[13,54,55]$, the quest for generating more stable p53 variants has been considerable, since it has implications in designing strategies for cancer therapies. The ultimate aim is not only to design a more thermodynamically stable protein, but also a properly folded and functionally active protein, which is capable of binding to DNA (i.e. p53 response elements). To further explore this aspect, we investigated the DNA binding properties of H115N and S116M using gadd45 as a model DNA binding sequence specific for p53. Our findings showed that both mutants from L1 loop bind to the DNA with similar affinity to that of the wildtype p53. It was reported that several mutations located in L1 loop enhance the affinity of p53 for select set of DNA sequences [22, 23, 33]. For instance, S121F mutant is known to induce apoptosis more effectively than wild-type p53, and to exhibit an increased affinity for some p53-binding sites. In recent report, Fen et al. selected p53 mutants that display altered DNA-binding specificities [34]. Interestingly the evolved variants contained substitutions in the L1 loop of the p53DBD, which showed increased transactivation of promoters and increase up-regulation of endogenous p21 relative to wild-type p53. Zupnick and Prives reported that T123A showed strikingly different and stronger affinity for p53 RE and that the mutant caused enhanced apoptosis relative to wild-type p53 in transfected cells [23]. However the molecular mechanisms of the above effects are not clear. 
Building on the above knowledge and our results about H115N and S116M we applied the second-site suppressors or "double mutant cycle" approach to test the effect of the above two mutants on the stability and DNA binding of key cancer-associated mutants. Specifically, we aimed to investigate if these two mutants from L1 loop would have any compensatory effect on the stability of the cancer-related mutants or trigger conformational changes on the latter or both. Strikingly, our studies revealed that the double mutant R248Q/H115N exhibited DNA binding for gadd45. This finding is significant given that $\mathrm{R} 248 \mathrm{Q}$, one of the most mutated residues in cancer and one of the only two DNA-contact mutants, does not exhibit DNA binding on its own. Furthermore, the observed effect is specific to R248Q, since the double mutant R248W/H115N does not seems to show enhanced DNA binding, when compared to R248W under similar conditions tested. Similarly, nether R248Q/S116M nor R248W/S116M showed any DNA binding for the same DNA sequence. In the absence of a crystal structure of the above mutants we performed molecular dynamic simulations of the two mutants of L1 loop, H115N and S116M as well as of the two double mutants $\mathrm{R} 248 \mathrm{Q} / \mathrm{H} 115 \mathrm{~N}$ and $\mathrm{R} 248 \mathrm{Q} / \mathrm{S} 116 \mathrm{M}$ to gain further understanding of the molecular mechanism of restoring DNA binding to R248Q by H115N. These data showed that indeed R248Q/H115 is structurally more similar to wild-type p53 than R248Q/S116M. From the computational data we observed that R248Q has similar conformation, especially in L1 loop, with the double mutant R248Q/S116M, which DNA binding was not restored. It should be noted that R248Q is unusual in that it is more than just a "contact" mutant since it is not hugely destabilised $(1.9 \mathrm{kcal} / \mathrm{mol}$ less stable than wild type p53) but the structures of loops L2 and L3 are perturbed [13, 52]. We applied the same experimental tests to a selection of other cancer mutants such as V143A, G245S, R249S, and R273H. All these four mutants are very different structurally; have different DNA binding as well as thermodynamic properties. For example, V143A is a temperature sensitive mutant and has partial DNA-binding, G245S is structural mutant that is moderately destabilized relative to wild-type p53 and has partial DNA binding, while R249S has no DNA binding and is less stable than wild-type p53 [13, 17, 34]. R273H has almost similar stability to that of wild-type p53 and despite the removal of an essential DNA-contact residue Arg-273, has some partial DNA binding. Recent X-ray structure attributed this to the localized structural changes, which do not perturb the overall scaffold of the DNA-binding surface [6]. It was also shown that global suppressors such as N239Y and $\mathrm{N} 268 \mathrm{D}$ rescued the function of G245S and V143A [12, 17]. This was ascribed to increase of the thermodynamic stability of $\mathrm{N} 239 \mathrm{Y}$ and $\mathrm{N} 268 \mathrm{D}$ resulting in the "compensatory effect" of rescue of the cancer-associated p53 mut0ations $[16,17]$. In addition, it has been reported that the function of G245S has been rescued by the second-site suppressor H178Y in an intermolecular manner [36]. The function of R249S was rescued by H168R and NMR studies showed that this was due to the induced conformational effects created by H168R rather than the increase of stability [17]. Structural studies have also revealed that R249S induces conformational changes and greater flexibility to Loop L3, which results in loss of stability and DNA binding. The function of Y220C, which accounts for a large number of human cancers, was rescued by a small drug which fills the cleft created by the point mutation, creates a surface cavity and destabilizes the protein [11].

The experimental and computational studies reported here show that mutants $\mathrm{H} 115 \mathrm{~N}$ and S116M from L1 loop stabilize the overall conformation of p53 DBD, while at the same time maintaining DNA binding for $\mathrm{p} 53$ response elements. Mutant $\mathrm{H} 115 \mathrm{~N}$ rescued the binding of the oncogenic mutant R248Q for gadd45 ds DNA. Further structure- 
function studies of R248Q/H115N, R248Q and the H115N would provide clues into the mechanism of rescue of $\mathrm{R} 248 \mathrm{Q}$. It is envisaged that screening libraries of small molecules would identify candidates that mimic the effect of the second-site suppressors and could be exploited in cancer therapy or as prototypes for structure-based drug design. Reactivation of cancer-associated mutants remains an important approach in designing strategies for cancer therapies. Better understanding of the molecular mechanism of mutant reactivation by second-site suppressors has the potential to provide new insights leading to novel drug developments.

\section{ACKNOWLEDGEMENTS}

We are grateful to Prof. Richard Cammack and Prof. Colin Dingwall for their helpful comments. Special thanks are due to Dr. Magali Olivier for providing latest data on the p53 database, R14, shortly before it was due for public release. This work was supported in part by the Ministry of education of Algeria (A.M.), the Biochemical Society (P.N.), the Nuffield Foundation (P.N.), the Royal Society Research grants (P.N.) and a shortterm FEBS fellowship to B.P.

\section{REFERENCES}

1. Bassett, E. A., Wang, W., Rastinejad, F., and El-Deiry, W. S. (2008) Structural and functional basis for therapeutic modulation of p53 signaling. Clin Cancer Res 14, 6376-6386.

2. Hupp, T. R., Lane, D. P., and Ball, K. L. (2000) Strategies for manipulating the p53 pathway in the treatment of human cancer. Biochem J 352 Pt 1, 1-17.

3. Leroy, K., Haioun, C., Lepage, E., Le Metayer, N., Berger, F., Labouyrie, E., Meignin, V., Petit, B., Bastard, C., Salles, G., Gisselbrecht, C., Reyes, F., and Gaulard, P. (2002) p53 gene mutations are associated with poor survival in low and low-intermediate risk diffuse large B-cell lymphomas. Ann Oncol 13, 1108-1115.

4. Sjoblom, T., Jones, S., Wood, L. D., Parsons, D. W., Lin, J., Barber, T. D., Mandelker, D., Leary, R. J., Ptak, J., Silliman, N., Szabo, S., Buckhaults, P., Farrell, C., Meeh, P., Markowitz, S. D., Willis, J., Dawson, D., Willson, J. K., Gazdar, A. F., Hartigan, J., Wu, L., Liu, C., Parmigiani, G., Park, B. H., Bachman, K. E., Papadopoulos, N., Vogelstein, B., Kinzler, K. W., and Velculescu, V. E. (2006) The consensus coding sequences of human breast and colorectal cancers. Science 314, 268-274.

5. Joerger, A. C., and Fersht, A. R. (2007) Structure-function-rescue: the diverse nature of common p53 cancer mutants. Oncogene 26, 2226-2242.

6. Joerger, A. C., and Fersht, A. R. (2008) Structural biology of the tumor suppressor p53. Annu Rev Biochem 77, 557-582.

7. Selivanova, G., and Wiman, K. G. (2007) Reactivation of mutant p53: molecular mechanisms and therapeutic potential. Oncogene 26, 2243-2254.

8. Guida, E., Bisso, A., Fenollar-Ferrer, C., Napoli, M., Anselmi, C., Girardini, J. E., Carloni, P., and Del Sal, G. (2008) Peptide aptamers targeting mutant p53 induce apoptosis in tumor cells. Cancer Res 68, 6550-6558.

9. Cho, Y., Gorina, S., Jeffrey, P. D., and Pavletich, N. P. (1994) Crystal structure of a p53 tumor suppressor-DNA complex: understanding tumorigenic mutations. Science 265, 346-355.

10. Joerger, A. C., and Fersht, A. R. (2007) Structural Biology of the Tumor Suppressor p53 and Cancer-Associated Mutants. Adv Cancer Res 97, 1-23.

11. Boeckler, F. M., Joerger, A. C., Jaggi, G., Rutherford, T. J., Veprintsev, D. B., and Fersht, A. R. (2008) Targeted rescue of a destabilized mutant of p53 by an in silico screened drug. Proc Natl Acad Sci U S A 105, 10360-10365. 
12. Brachmann, R. K., Yu, K., Eby, Y., Pavletich, N. P., and Boeke, J. D. (1998) Genetic selection of intragenic suppressor mutations that reverse the effect of common p53 cancer mutations. EMBO J 17, 1847-1859.

13. Bullock, A. N., Henckel, J., DeDecker, B. S., Johnson, C. M., Nikolova, P. V., Proctor, M. R., Lane, D. P., and Fersht, A. R. (1997) Thermodynamic stability of wild-type and mutant p53 core domain. Proc Natl Acad Sci U S A 94, 14338-14342.

14. Friedler, A., Hansson, L. O., Veprintsev, D. B., Freund, S. M., Rippin, T. M., Nikolova, P. V., Proctor, M. R., Rudiger, S., and Fersht, A. R. (2002) A peptide that binds and stabilizes p53 core domain: chaperone strategy for rescue of oncogenic mutants. Proc Natl Acad Sci U S A 99, 937-942.

15. Issaeva, N., Friedler, A., Bozko, P., Wiman, K. G., Fersht, A. R., and Selivanova, G. (2003) Rescue of mutants of the tumor suppressor p53 in cancer cells by a designed peptide. Proc Natl Acad Sci U S A 100, 13303-13307.

16. Nikolova, P. V., Henckel, J., Lane, D. P., and Fersht, A. R. (1998) Semirational design of active tumor suppressor p53 DNA binding domain with enhanced stability. Proc Natl Acad Sci U S A 95, 14675-14680.

17. Nikolova, P. V., Wong, K. B., DeDecker, B., Henckel, J., and Fersht, A. R. (2000) Mechanism of rescue of common p53 cancer mutations by second-site suppressor mutations. EMBO J 19, 370-378.

18. Ang, H. C., Joerger, A. C., Mayer, S., and Fersht, A. R. (2006) Effects of common cancer mutations on stability and DNA binding of full-length p53 compared with isolated core domains. J Biol Chem 281, 21934-21941.

19. Pan, Y., Ma, B., Venkataraghavan, R. B., Levine, A. J., and Nussinov, R. (2005) In the quest for stable rescuing mutants of p53: computational mutagenesis of flexible loop L1. Biochemistry 44, 1423-1432.

20. Pan, Y., and Nussinov, R. (2008) p53-Induced DNA bending: the interplay between p53-DNA and p53-p53 interactions. J Phys Chem B 112, 6716-6724.

21. Ahn, J., Poyurovsky, M. V., Baptiste, N., Beckerman, R., Cain, C., Mattia, M., McKinney, K., Zhou, J. M., Zupnick, A., Gottifredi, V., and Prives, C. (2009) Dissection of the sequence-specific DNA binding and exonuclease activities reveals a superactive yet apoptotically impaired mutant p53 protein. Cell Cycle 8, 1603-1615.

22. Inga, A., and Resnick, M. A. (2001) Novel human p53 mutations that are toxic to yeast can enhance transactivation of specific promoters and reactivate tumor p53 mutants. Oncogene 20, 3409-3419.

23. Zupnick, A., and Prives, C. (2006) Mutational analysis of the p53 core domain L1 loop. J Biol Chem 281, 20464-20473.

24. Zhao, K., Chai, X., Johnston, K., Clements, A., and Marmorstein, R. (2001) Crystal structure of the mouse p53 core DNA-binding domain at 2.7 A resolution. J Biol Chem 276, 12120-12127.

25. Joerger, A. C., Allen, M. D., and Fersht, A. R. (2004) Crystal structure of a superstable mutant of human p53 core domain. Insights into the mechanism of rescuing oncogenic mutations. J Biol Chem 279, 1291-1296.

26. Joerger, A. C., Ang, H. C., and Fersht, A. R. (2006) Structural basis for understanding oncogenic p53 mutations and designing rescue drugs. Proc Natl Acad Sci U S A 103, 15056-15061.

27. Joerger, A. C., Ang, H. C., Veprintsev, D. B., Blair, C. M., and Fersht, A. R. (2005) Structures of p53 cancer mutants and mechanism of rescue by second-site suppressor mutations. J Biol Chem 280, 16030-16037.

28. Suad, O., Rozenberg, H., Brosh, R., Diskin-Posner, Y., Kessler, N., Shimon, L. J., Frolow, F., Liran, A., Rotter, V., and Shakked, Z. (2009) Structural basis of restoring 
sequence-specific DNA binding and transactivation to mutant p53 by suppressor mutations. J Mol Biol 385, 249-265.

29. Ho, W. C., Fitzgerald, M. X., and Marmorstein, R. (2006) Structure of the p53 core domain dimer bound to DNA. J Biol Chem 281, 20494-20502.

30. Kitayner, M., Rozenberg, H., Kessler, N., Rabinovich, D., Shaulov, L., Haran, T. E., and Shakked, Z. (2006) Structural basis of DNA recognition by p53 tetramers. Mol Cell 22, 741-753.

31. Pan, Y., Ma, B., Levine, A. J., and Nussinov, R. (2006) Comparison of the human and worm p53 structures suggests a way for enhancing stability. Biochemistry 45, 39253933.

32. Inga, A., Monti, P., Fronza, G., Darden, T., and Resnick, M. A. (2001) p53 mutants exhibiting enhanced transcriptional activation and altered promoter selectivity are revealed using a sensitive, yeast-based functional assay. Oncogene 20, 501-513.

33. Saller, E., Tom, E., Brunori, M., Otter, M., Estreicher, A., Mack, D. H., and Iggo, R. (1999) Increased apoptosis induction by 121F mutant p53. EMBO J 18, 4424-4437.

34. Fen, C. X., Coomber, D. W., Lane, D. P., and Ghadessy, F. J. (2007) Directed evolution of p53 variants with altered DNA-binding specificities by in vitro compartmentalization. J Mol Biol 371, 1238-1248.

35. Baroni, T. E., Wang, T., Qian, H., Dearth, L. R., Truong, L. N., Zeng, J., Denes, A. E., Chen, S. W., and Brachmann, R. K. (2004) A global suppressor motif for p53 cancer mutants. Proc Natl Acad Sci U S A 101, 4930-4935.

36. Otsuka, K., Kato, S., Kakudo, Y., Mashiko, S., Shibata, H., and Ishioka, C. (2007) The screening of the second-site suppressor mutations of the common p53 mutants. Int $\mathbf{J}$ Cancer 121, 559-566.

37. Friedler, A., DeDecker, B. S., Freund, S. M., Blair, C., Rudiger, S., and Fersht, A. R. (2004) Structural distortion of p53 by the mutation R249S and its rescue by a designed peptide: implications for "mutant conformation". J Mol Biol 336, 187-196.

38. Patel, S., Bui, T. T. T., Drake, A. F., Fraternali, F., and Nikolova, P. V. (2008) The p73 DNA Binding Domain Displays Enhanced Stability Relative to Its Homologue, the Tumor Suppressor p53, and Exhibits Cooperative DNA Binding. Biochemistry 47, 3235-3244.

39. Patel, S., George, R., Autore, F., Fraternali, F., Ladbury, J. E., and Nikolova, P. V. (2008) Molecular interactions of ASPP1 and ASPP2 with the p53 protein family and the apoptotic promoters PUMA and Bax. Nucleic Acids Res 36, 5139-5151.

40. Warren, L. (2006) The PyMOL Molecular Graphics System. DeLano Scientific LLC, SanCarlos, CA, USA.

41. Wang, Y., Rosengarth, A., and Luecke, H. (2007) Structure of the human p53 core domain in the absence of DNA. Acta Crystallogr D Biol Crystallogr. D Biol Crystallogr., 63, 276-281.

42. Hess, B., Kutzner, C., van Der Spoel, D., and Lindahl, E. (2008) Gromacs 4: Algorithms for highly efficient, load-balanced, and scalable molecular simulation. J. Chem. Theory Comput., 4, 435-447.

43. Oostenbrink, C., Villa, A., Mark, A.E., Van Gunsteren, W.F. (2004) A biomolecular force field based on the free enthalpy of hydration and solvation: The GROMOS force-field parameter sets 53A5 and 53A6. J. Comput. Chem., 25, 1656-1676.

44. Berendsen, H. J. C., Postma, J. P. M., van Gunsteren, W. F., Hermans, J., and Pullman, B. (1981) Intermolecular Forces. 331-342.

45. Hess, B., Bekker, H., Berendsen, H.J.C. and Fraaije, J. (1997) LINCS: a linear constraint solver for molecular simulation. J. Comput. Chem., 18, 1463-1472. 
46. Berendsen, H. J. C., Postma, J. P. M., van Gunsteren, W. F., Dinola, A., and Haak, J. R. (1984) Molecular dynamycs with coupling to an external bath. J. Chem. Phys. 81, 3684-3690.

47. Bussi, G., Donadiao, D. and Parrinello, M. (2007) Canonical Sampling through velocity rescaling. J. Chem. Phys., 126.

48. Essmann, U., Perera,L., Berkowitz, M.L., Darden, T., Lee, H., and Pedersen, L.G. (1995) A smooth particle mesh Eswald method. J. Chem. Phys., 103, 8577-8593.

49. Barrett, P., Hall, B.A., and Noble, M.E.M. . (2004) Dynamite: Asimple way to gain insight into protein motions. Acta Crystallogr D Biol Crystallogr., 60, 2280-2287.

50. Humphrey, W., Dalke, A. and Schulten, K. (1996) VMD: Visual Molecular dynamycs. J. Mol. Graph., 14, 33-38.

51. Friedler, A., Veprintsev, D. B., Hansson, L. O., and Fersht, A. R. (2003) Kinetic instability of p53 core domain mutants: implications for rescue by small molecules. J Biol Chem 278, 24108-24112.

52. Wong, K. B., DeDecker, B. S., Freund, S. M. V., Proctor, M. R., Bycroft, M., and Fersht, A. R. (1999) Hot-spot mutants of p53 core domain evince characteristic local structural changes. Proc Natl Acad Sci U S A 96, 8438-8442.

53. Mayer, S., Rudiger, S., Ang, H. C., Joerger, A. C., and Fersht, A. R. (2007) Correlation of levels of folded recombinant p53 in escherichia coli with thermodynamic stability in vitro. J Mol Biol 372, 268-276.

54. Lu, Q., Tan, Y.-H. and Luo, R. (2007) Molecular dynamics simulations of p53 DNABinding Domain. J. Phys Chem B. 111, 11538-11545.

55. Madhumalar, A., Smith, D.J. and Verma, C. (2008) Stability of the core domain of p53: insights from computer simulations. BMC Bioinformatics 9, 1-15. 


\section{FIGURE LEGENDS}

Figure 1. Ribbon representation of p53 DBD. The residues mutated in the experiments are highlighted in cyan, while the residues mutated in both experimental and computational studies are shown in blue. The zinc is represented as a purple sphere.

Figure 2. The variable temperature Far-UV CD spectra of the p53 single mutants at: $\left(-{ }_{-}\right.$ $20^{\circ} \mathrm{C}$; (一-) $4^{\circ} \mathrm{C}$; (一) $37^{\circ} \mathrm{C}$ : (A) WTp53; (B) H115N; (C) S116M; (D) R248Q; (E) R248W; (F) R249S; (G) R273H; (H) V143A, (I) G245S.

Figure 3. The variable temperature Far-UV CD spectra of the p53 double mutants at: (—) $20^{\circ} \mathrm{C}$; (一॰) $4^{\circ} \mathrm{C}$; (- $37^{\circ} \mathrm{C}$ : (A) R248Q/H115; (B) R248Q/S116M; (C) R248W/H115N; (D) R248W/S116M; (E) R273H/H115N; (F) R273H/S116M; (G) R249S/H115N; (H) R249S/S116M, (I) V143A/H115N, (J) G245S/H115N

Figure 4. Apparent melting temperature (Tm) profiles of wild-type p53 DBD and various mutants, recorded at $222 \mathrm{~nm}$ in $10 \mathrm{mM} \mathrm{NaP}, 100 \mathrm{mM} \mathrm{NaCl}$ and $4 \mathrm{mM} \mathrm{DTE}, \mathrm{pH}$ 7.2.

Figure 5. EMSA of wild type and p53 mutants to test their DNA binding to gadd45. An increasing amount of protein concentrations were titrated into a fixed amount of DNA concentration $\left(5 \times 10^{-6}\right)$, using TB running buffer, at $60-90 \mathrm{~V}$ for ca $50 \mathrm{~min}$ at RT.

Figure 6. Ribbon representation of the starting (transparent) and final (opaque) structures for the wild-type p53, H115N and S116M mutants. RMSF of $\mathrm{C} \alpha$ atoms of wild-type p53 (black), $\mathrm{H} 115 \mathrm{~N}$ (red) and S116M (green) mutants, computed over the last $4 \mathrm{~ns}$ of the trajectories. Secondary structure is displayed along the sequence: $\alpha$-helices and $\beta$-strands are shown by red rectangles and green arrows, respectively.

Figure 7. (A) Starting and (B) final structures of R248Q mutant. The distance between C $\alpha$ atom of residue 248 and $\mathrm{C} \alpha$ atom of the closest residue belonging to $\mathrm{H} 2$ (residue 285) and the distance between the $\mathrm{C} \alpha$ atoms of the two closest residues belonging to H2 and L1 loop (residues 279 and 118, respectively) are shown. (C) Superposition of the structures of wildtype p53 core domain (transparent black), R248Q/H115N (cyan) and R248Q/S116M (magenta) and (D) C $\alpha$ RMSD of L1 loop (residues 113-123) of p53 core domain (black), R248Q/H115N (cyan) and R248Q/S116M (magenta).

Table 1. Number of total intra-molecular h-bonds, h-bonds formed by residues of the L1 loop and S2 strand (stretch of residues 113-126) and by this stretch with the H2 helix residues (residues 277-289). 


\section{Figure 1.}

\section{Penka V. Nikolova}

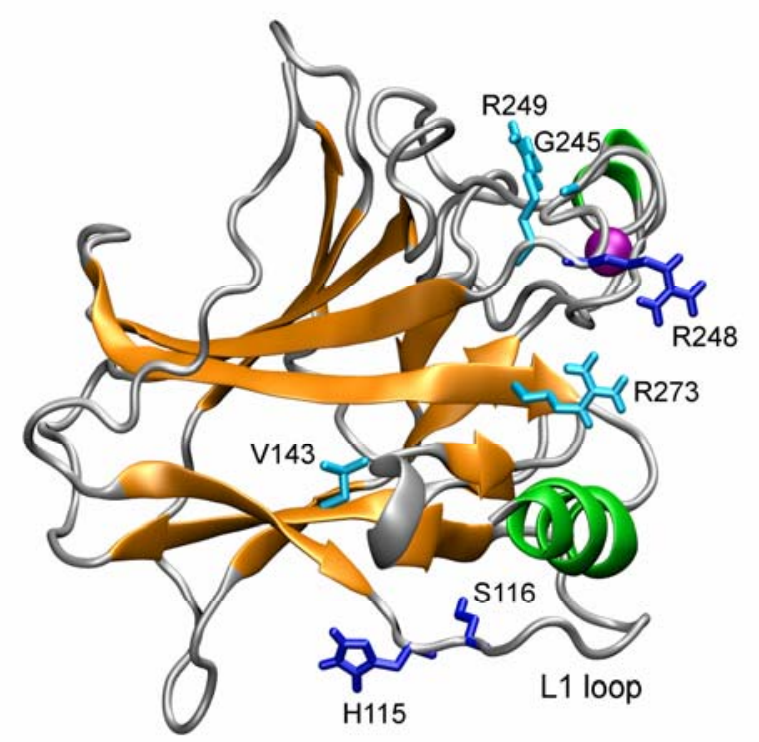


Figure 2.

Penka V. Nikolova

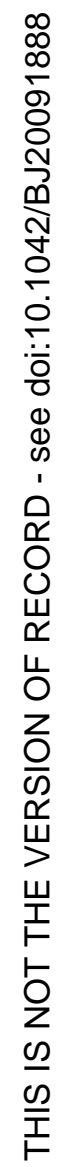
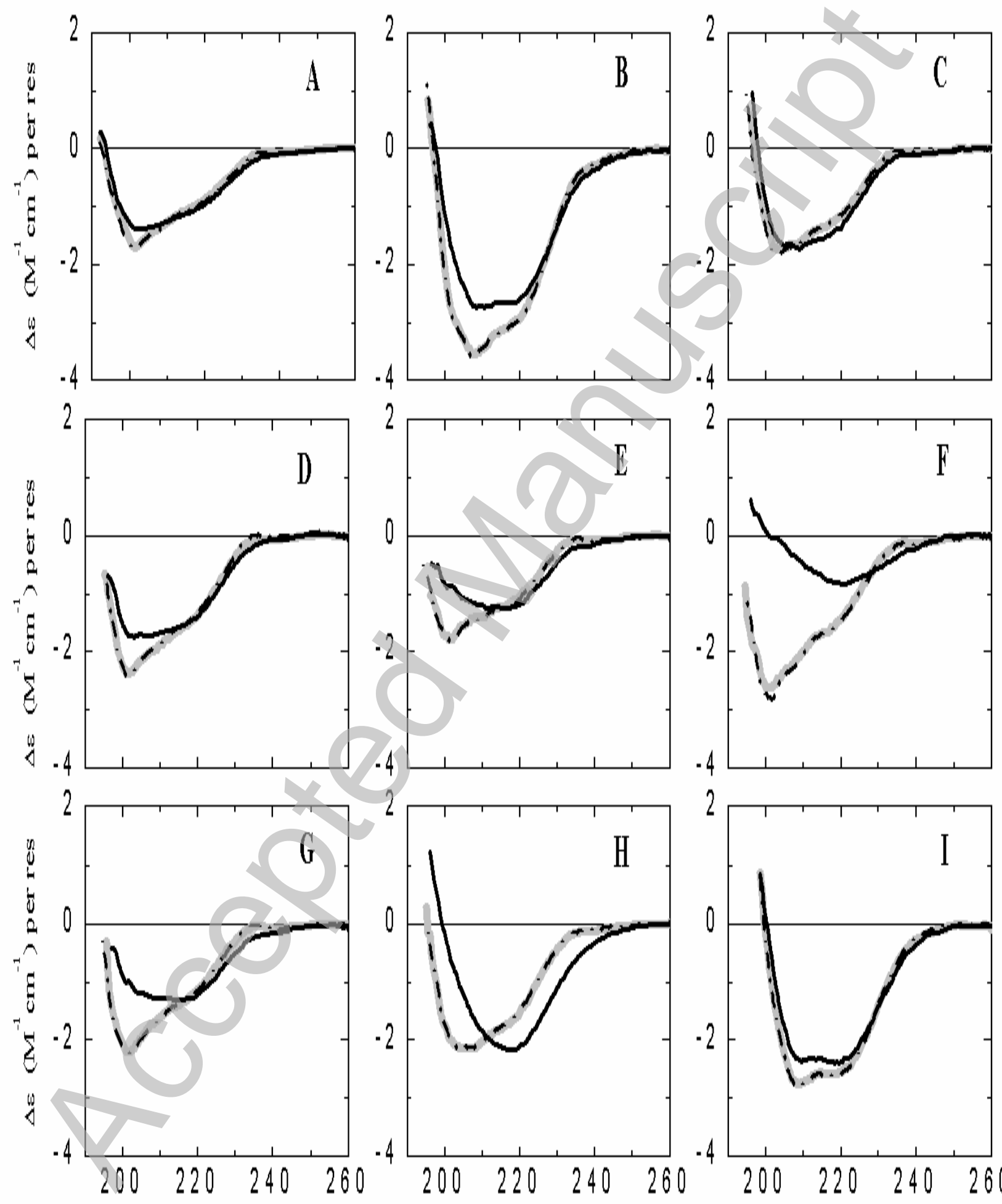

W avelength (nm)

Wavelength (nm)

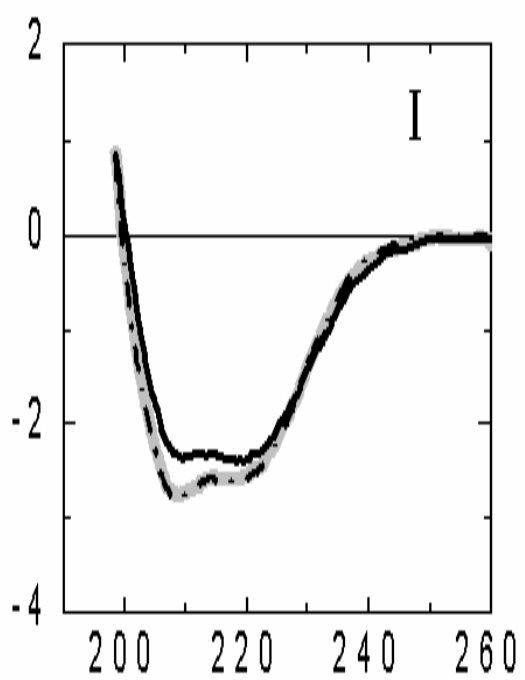

W avelength (nm)

Licenced copy. Copying is not permitted, except with prior permission and as allowed by law.

(C) 2010 The Authors Journal compilation @ 2010 Portland Press Limited 


\section{Figure 3.}

\section{Penka V. Nikolova}
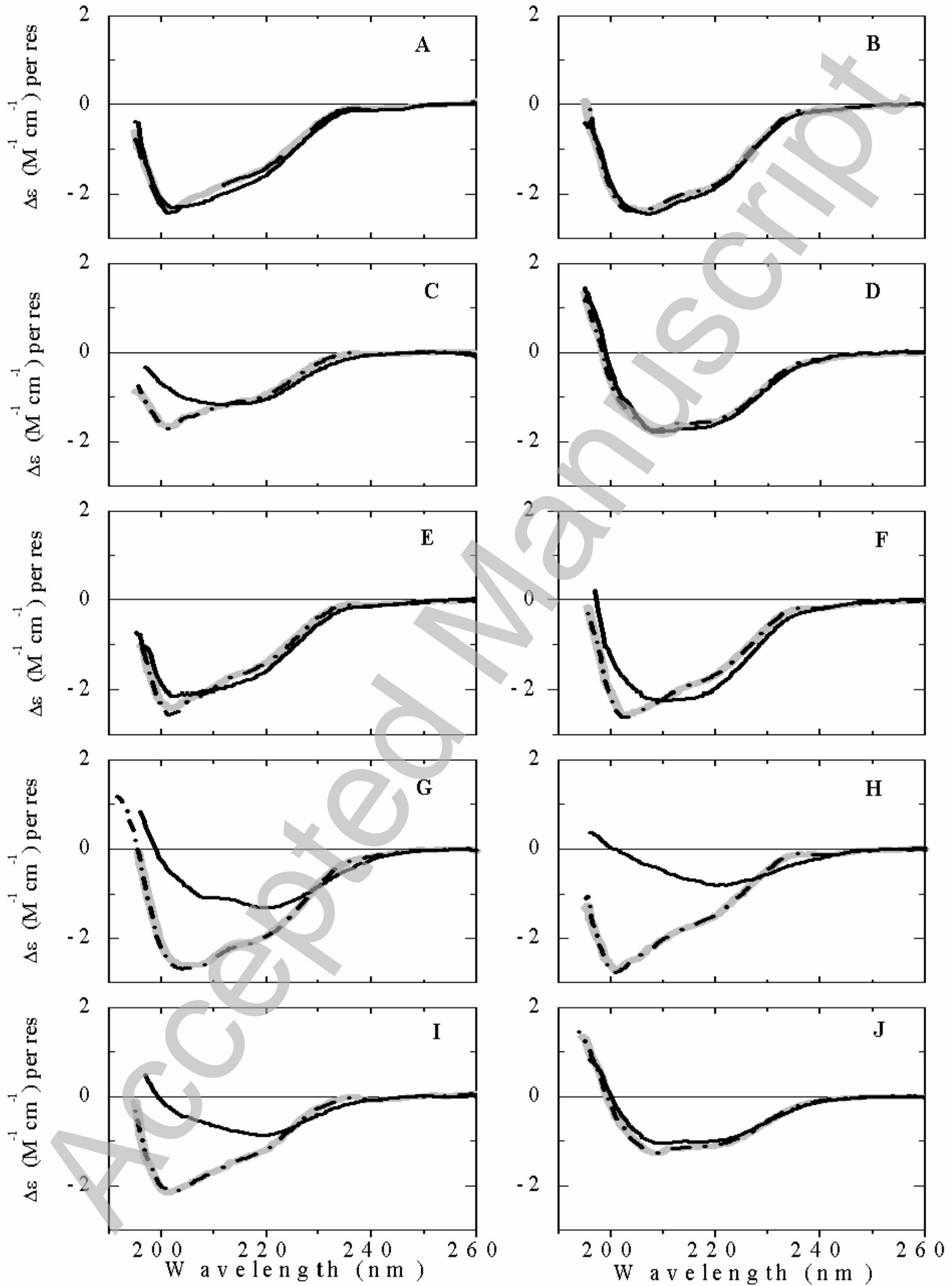

Licenced copy. Copying is not permitted, except with prior permission and as allowed by law. 


\section{Figure 4.}

\section{Penka V. Nikolova}

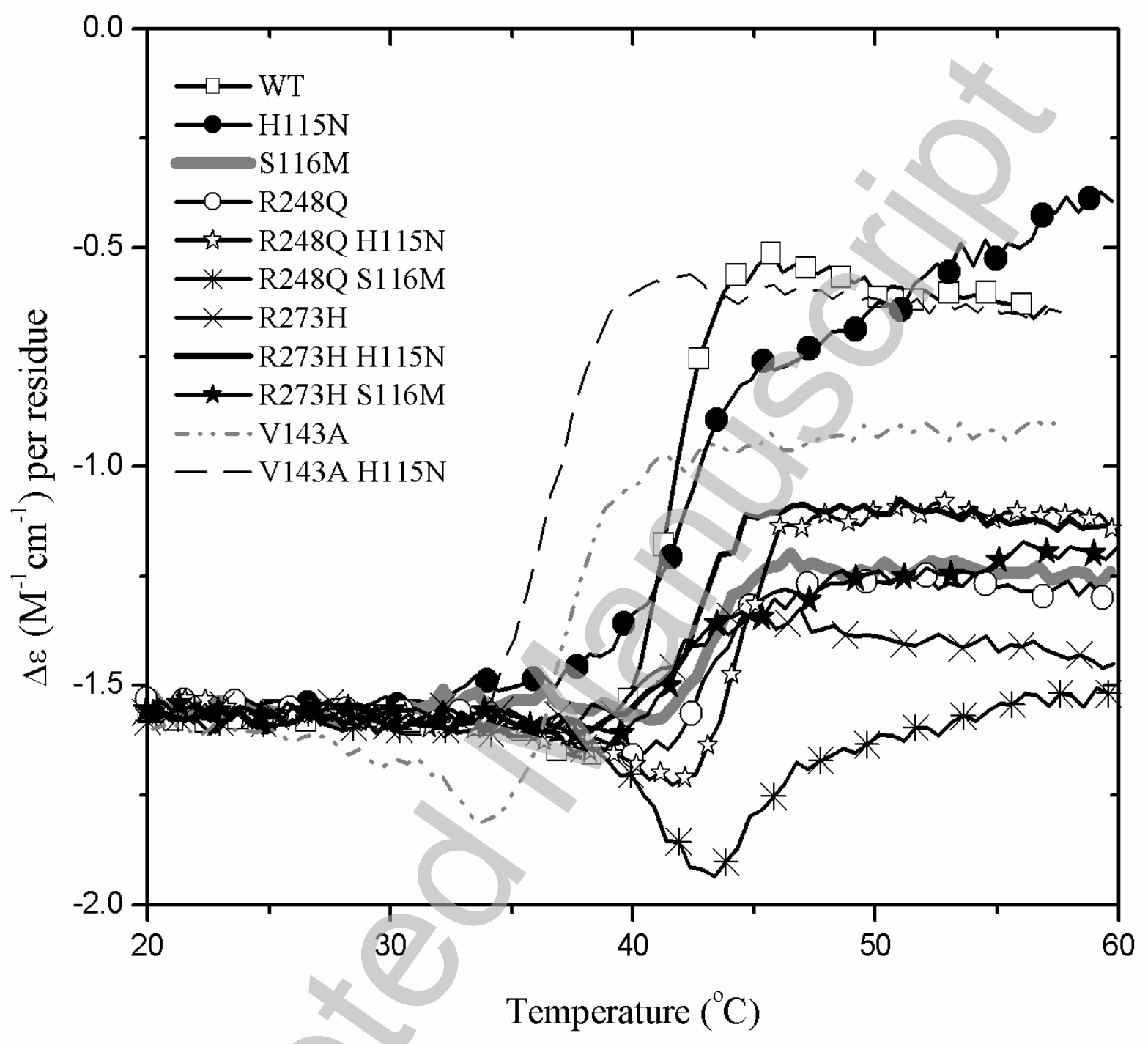




\section{Figure 5.}

Penka V. Nikolova
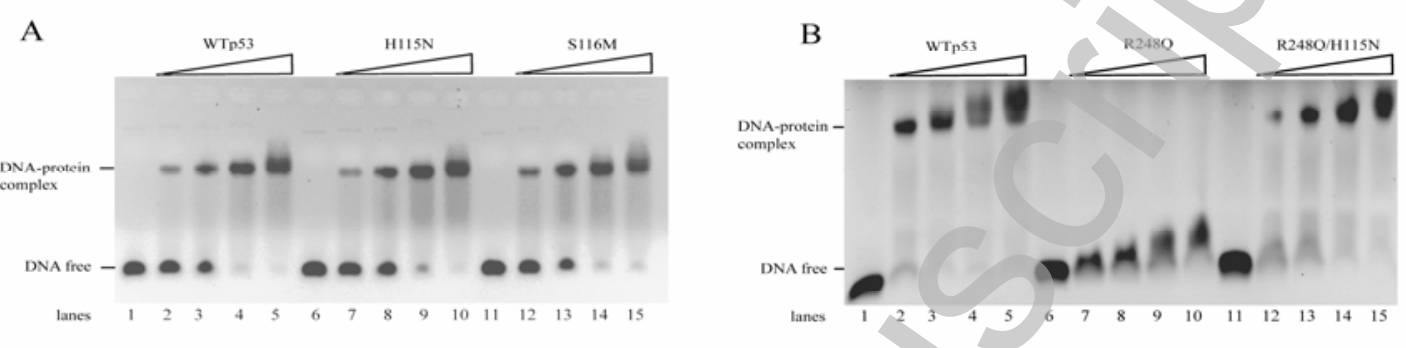

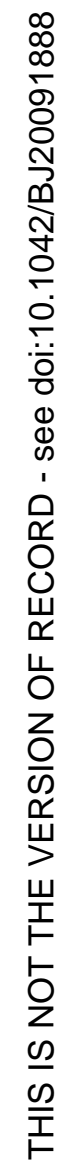
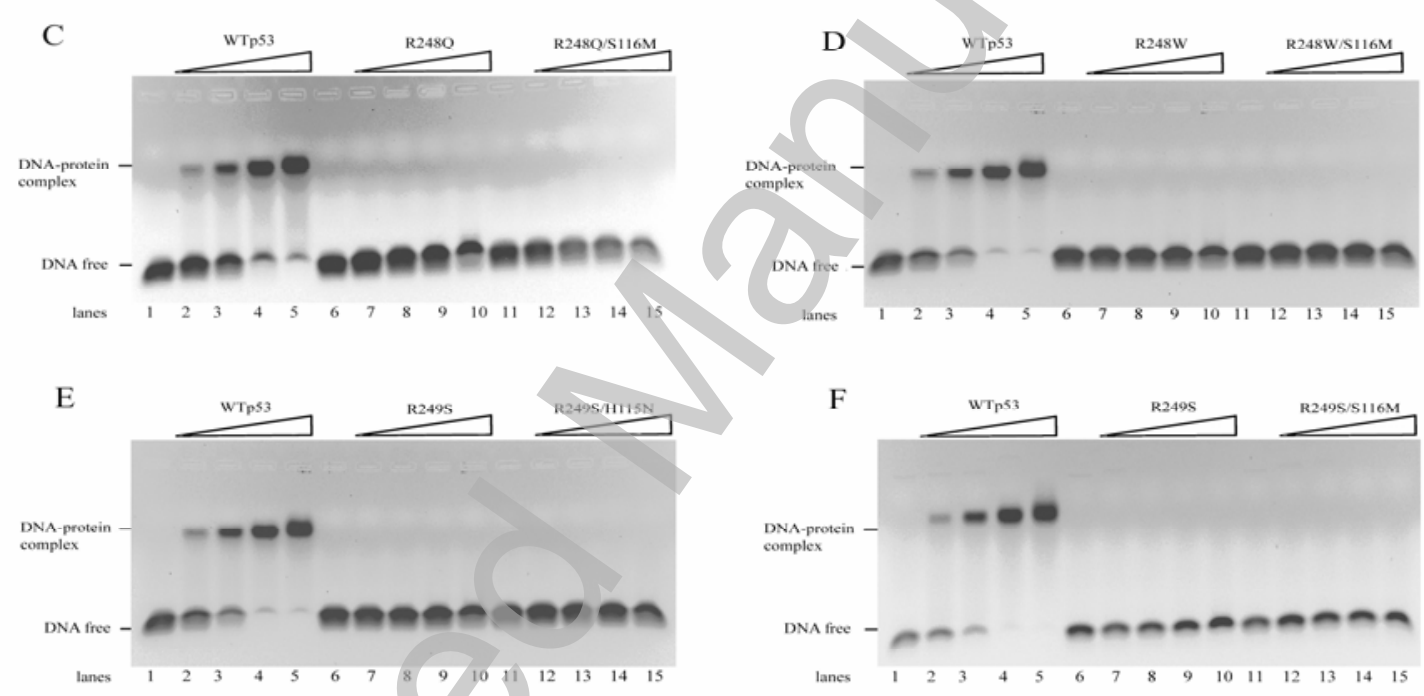


\section{Figure 6}

\section{Penka V. Nikolova}

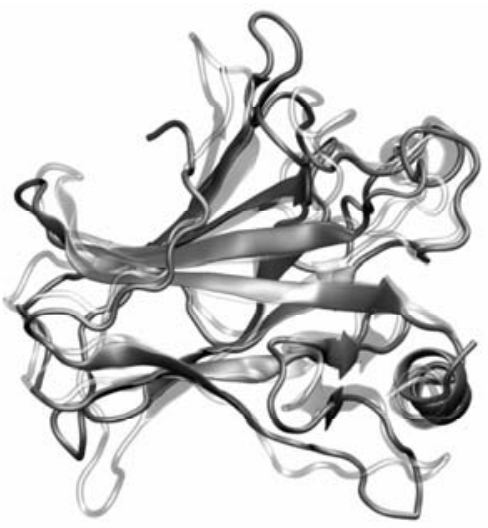

WT

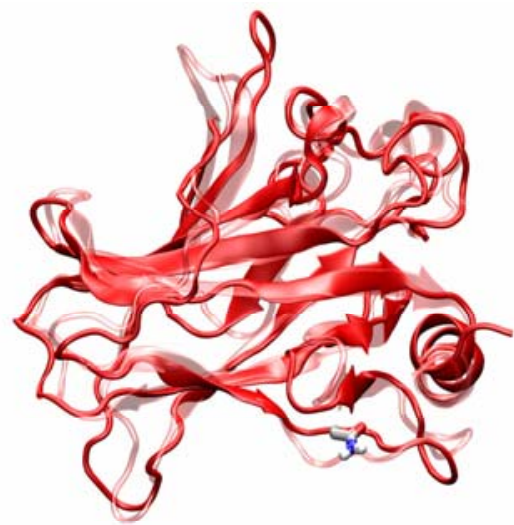

$\mathrm{H} 115 \mathrm{~N}$

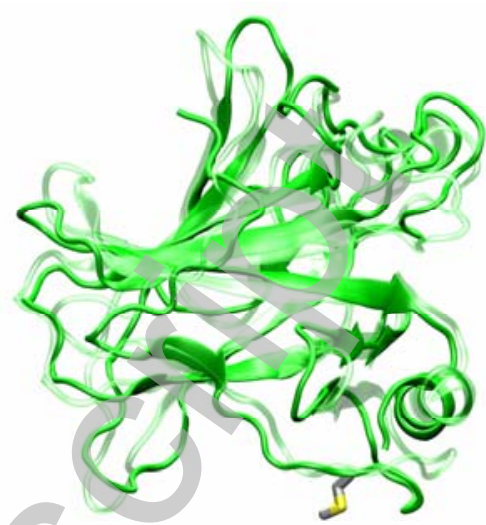

$\mathrm{S} 116 \mathrm{M}$

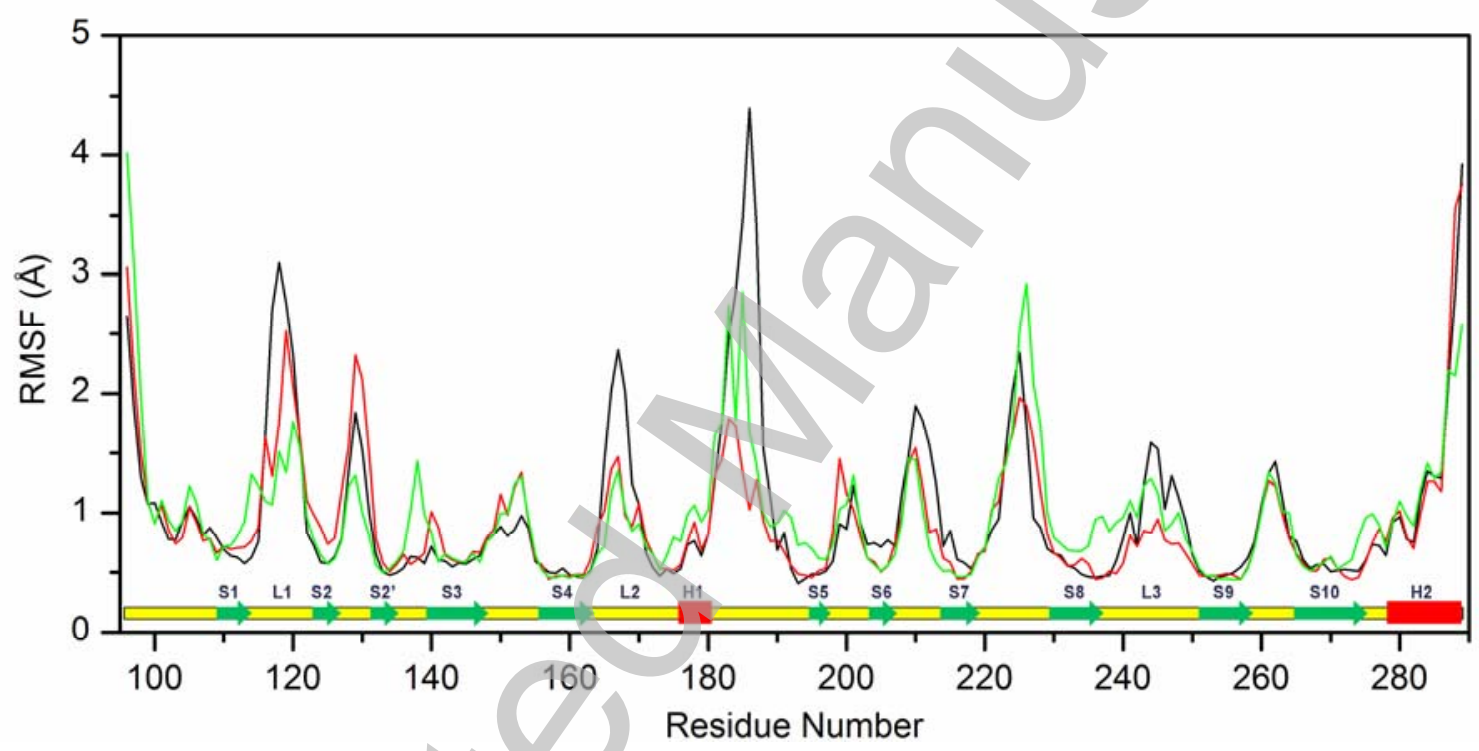




\section{Figure 7}

\section{Penka V. Nikolova}

A

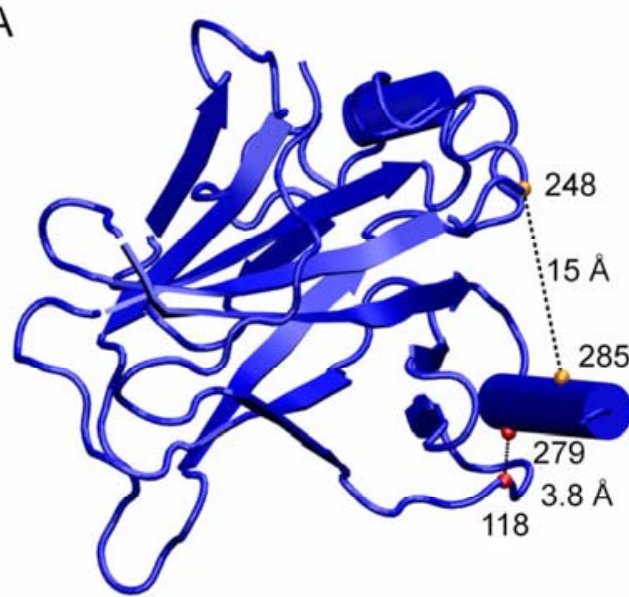

C

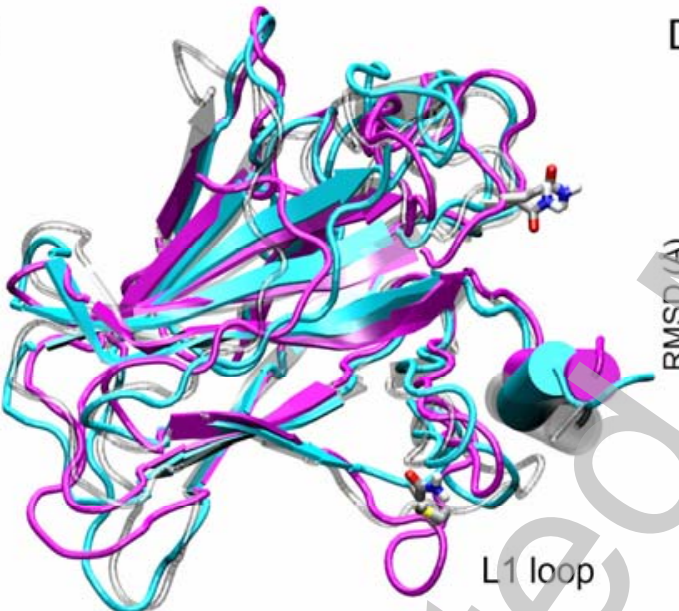

B

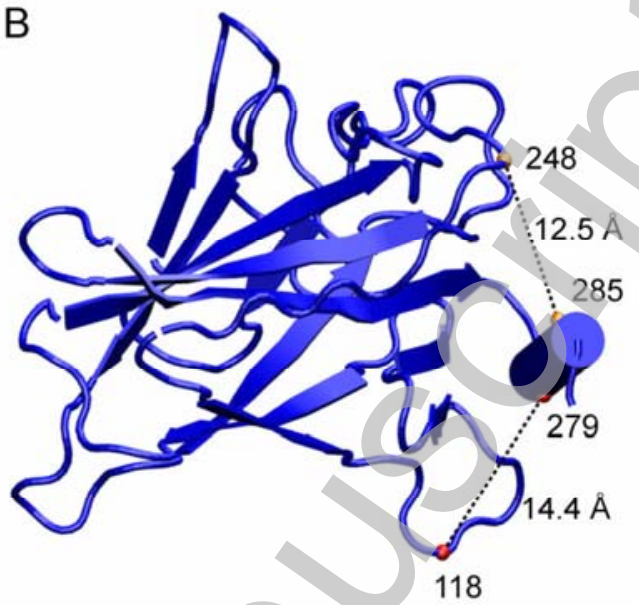

D

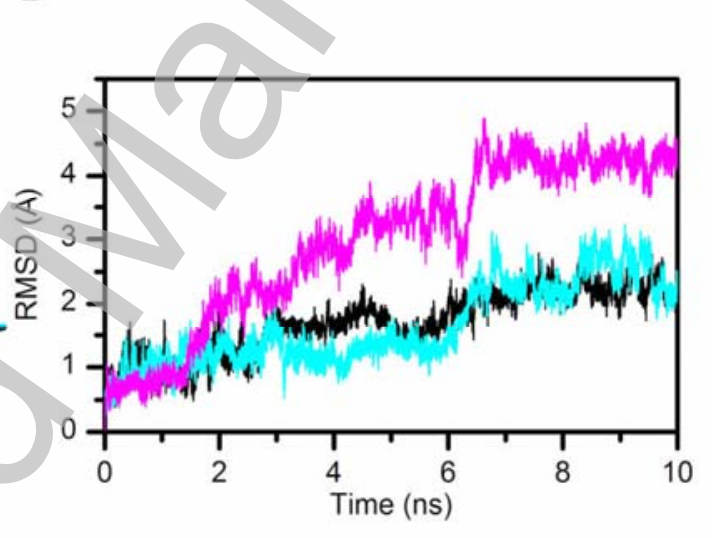


Table 1. Number of total intra-molecular h-bonds, of h-bonds formed by residues of the L1 loop and S2 strand (stretch of residues 113-126) and by this stretch with the H2 helix residues (residues 277-289)

\begin{tabular}{lrrr}
\hline & Total & L1 loop & L1 loop-H2 helix \\
\hline WT & 119 & 3 & 1 \\
H115N & 121 & 5 & 1 \\
S116M & 117 & 1 & 2 \\
R248Q & 120 & 3 & 0 \\
R248Q/H115N & 121 & 5 & 1 \\
R248Q/S116M & 119 & 2 & 0 \\
\hline
\end{tabular}

